\title{
Plasma Gasification as an Alternative Technology for the Treatment of Waste in Kano State, Nigeria: A Proposed Model
}

\author{
Aminu Mansur \\ Department of urban and Regional Planning, Hussaini Adamu Federal Polytechnic, Kazaure, Nigeria
}

\begin{abstract}
The study aimed at proposing a model an (advance technology) known as Plasma gasification as an alternative technology for the treatment of waste. The paper portray the technology and unveiled it relevance and efficiency in waste management system. The findings reveals, among other things, that plasma technology is still not recognized in the study area, some environmental constraints ranging from erratic electricity supply and cost have to a large extent hindered the utilization and efficient performance of this type of technology, that waste generation and disposal is increasing at alarming rate due to urban growth, economic activities and increasing population. Similarly, being a commercial centre coupled with high concentration of industries, these activities also give rise to huge volume of Municipal solid waste generation and disposal practices making it management to be a major environmental problem affecting the study area. Although, the amount of waste generation and disposal on daily basis could not be precisely established due to lack of inclusive and consistent data base on waste management. The paper concludes that waste management system is at it lowest ebb and thus, open dumping is currently practice with few segment of the population engaged in scavenging.
\end{abstract}

Keywords: Plasma technology, Municipal solid waste, Solid waste, hazardous waste.

\section{Introduction}

Plasma gasification has recently received little attention in Nigeria. Interest in waste treatment using this type of technology is still very low despite its importance in waste management. In spite of few studies in this area, e.g (Anyaegbunam 2013, Anyaegbunam 2014 and Anyaegbunam 2013) among others, a consensus has not yet emerged on the operation and efficacy of plasma technology in Kano state (Northern part of Nigeria), provision of constant electricity supply to enhance its performance is particularly difficult. Studies on waste management disregarding the role of plasma technology is an issue of debate among scholars.

Jannelli et al. (2014) reported that current studies centered on modern technology based on thermal plasma gasification that appear to be the most efficient and environmentally pleasant system for solid waste management and energy consumption. Appropriate gases in plasma involved hydrogen, nitrogen, argon as well as oxygen and air.

The performance of thermal plasma gasification has been demonstrated in many other studies e.g Byun et al. (2011), Zhang et al. (2012), Galeno et al. (2011), Danthurebandara et al. (2014) and Gray (2014) among others and concluded that plasma gasification is the most proficient and environmentally nice method for solid waste management.

Galeno et al. (2011) observed that owing to the growing quantity of waste materials generated directly from industries and other residential areas in several countries of the world, waste management is becoming a critical issue particularly in recent years. The major policy behind waste management are the increase of material recovery which can trim down the landfill disposal, the enhancement of energy recovery from waste and lessen the environmental impact.
In a review of related literature Mountouris et al. (2005) demonstrated that plasma technology is a non incineration thermal process that harness high temperature in an environment that extremely requires oxygen to decompose completely the input waste material in to very simple molecule.

Consoni et al. (2011) noted that any waste material can be broken down through the technique of plasma removing time consuming, tedious and costly process of sorting out waste by hand. However, Araya et al. (2006) observed that various industries adopt the use of thermal plasma for numerous processing activities ranging from modifying the surface of polymer material, as well as cleaning or coating the surface of several materials.

Gomez et al. (2009) argued that industrial development and population growth have resulted to rapid increased in the volume of hazardous waste and municipal solid waste (MSW) generated globally making it management to be a major environmental problem affecting many urban centers. Several techniques ranging from incineration, pyrolysis and melting have emerged for treating these hazardous wastes prior to disposal. Their aim is to destroy the organic fraction and transform the inorganic fraction in to an inert silicate slag or glass that can be advantageously re-used or harmlessly disposed in landfill.

Zhao et al. (2010) reported that in many urban cities locating a designated area for landfills has remained a problem and incineration has been popularly known as the technique of waste disposal but unfortunately, series of problems have in one way or the other affect the efficient functioning of the system such as contamination with dioxin and heavy metals.

Consoni et al. (2011) investigated the performance of plasma system for treating medical wastes and has been 


\section{International Journal of Science and Research (IJSR) \\ ISSN (Online): 2319-7064}

Index Copernicus Value (2013): 6.14 | Impact Factor (2014): 5.611

tested in Korea using various surrogate model. The findings revealed that bacteria and other wastes were completely destroyed when exposed to the reactive environment of plasma due to the high temperatures.

Shekdar (2006) studied plasma technology and compared with conventional waste treatment in an experiments with simulated hospital wastes at the institute of plasma Research in India. The results showed that gases obtained after prolysis are rich in hydrogen and carbon monoxide with some lower molecular weight hydrocarbons and therefore could be used to recover energy.

There has not been any relatively published research on Plasma gasification at international level in the study area and thus, this study attempt to bridge the gap, mainly by introducing a modern technology for the treatment of waste. Identifying and implementing the expertise of the aforementioned technology would contribute significantly in reducing the volume of waste disposal and create awareness, interest and knowledge in waste management system. Based on the above background therefore, the study aim at proposing a model an advance technology known as Plasma gasification as an alternative technology for the treatment of waste.

\section{The Study Area}

The study is confined to Kano state (Northern part of Nigeria). It is approximately located on latitude $12^{02, \mathrm{~N}}$ and longitude $8^{0} 22$,E Statistical analysis revealed that mean annual temperature is about $27^{\circ} \mathrm{C}$ with mean annual rainfall of $1000 \mathrm{~mm}$. Similarly, the rainfall season usually commences from May/June and stop in September lasting up to early October in some occasions, the remaining part of the year is dry. Relative humidity is high mostly around March-May lingering up to June normally between 90\%, but a comprehensive evaluation of this condition suggests that the humidity fluctuate over time with the on set of rainfall and also during harmattan season.

\section{Methodology}

Reconnaissance survey of various designated disposal site within the study area were carried out for a period three years between $\left(15^{\text {th }}\right.$ July,2012-15 $5^{\text {th }}$ July,2015) in order to assess the nature of waste generation and mode of disposal. Content analysis of information and focused group discussion with stakeholders were also adopted during which data was collected over a period of time. This is with a view to consider the possibility of proposing a current waste management system known as plasma gasification.

\section{Results}

Plasma gasification is generally regarded as one of the most efficient method for the treatment of waste, although the emergence of this technology and the role play in waste treatment is still not recognize in Kano state inspite of it importance in waste management. It has been observed that some environmental limitations ranging from unreliable electricity supply and cost have to a large extent hindered the utilization and efficient performance of this type of technology.

The study found that generation and disposal of solid waste materials is always on the increasing trend due to rapid population growth, economic activities as well as urbanization. Similarly, being a commercial center with bigger major markets in different locations within the city for example, Sabon Gari market, Kanti Kwari market, Singa, Kurmi market and Wanbai market to mentioned a few such development give rise to huge volume of MSW generation and haphazard disposal practice making it management to be a major problem. Although, the extent of waste generation and disposal cannot be accurately established due to lack of inclusive and dependable data base on waste management.

The findings however, revealed that waste management system is accorded low priority and thus, open dumping which is the most backward system of waste disposal is currently practice with few segment of the population engaged in scavenging.

Therefore, with the break through in modern science and technology and subsequent invention of plasma technology would help in no small measure to tackle the problem of waste disposal and its associated threats to environment and human health. In addition, shrink the quantity of waste and lessen emission.

Gandhul (2015) reported that plasma gasification of waste avert several ecological consequence that occur owing to burning of waste material and landfill. Gasification is more advance compared to landfill for a few reasons. Landfills are poisonous due to the assembly of harmful leachate, liquid and methane gas. Similarly, corrosion and chemical effects associated with the waste generate fluid that filter out and consequently pollute ground water.

It has been observed that Kano state is a commercial center with high concentration of industries for example, standard foot wear Nigerian Limited, Sabi Plastic company, Nakowa plastic company, Delta plastic company among others generate a considerable amount of wastes which significantly pollute the urban environment. These companies would no doubt require the use of plasma technology to transform and glaze the surface of polymer material and other processing activities and considerably reduce the quantity of waste.

Currently, due to urbanization and continue town expansion construction of new settlements, reconstruction, repairs and construction of bridges in urban Kano is presently going on, but unfortunately, designated disposal sites could not alone accommodate the massive volume of waste resulting from such activities. Therefore, the debris generated directly from the sites could all undergo plasma treatment.

This is in consonance with Anyaegbunam (2014) observation where he argued that many waste treatment/disposal systems have been assessed with a view to ensure environmental remediation of harmful polluted materials. Environmental vulnerability of wastes from military institutions, asbestos from knock down structures 


\section{International Journal of Science and Research (IJSR) \\ ISSN (Online): 2319-7064 \\ Index Copernicus Value (2013): 6.14 | Impact Factor (2014): 5.611}

and perilous wastes from hospitals could not be lessen by landfill alone. It was found that medical wastes generated directly from various hospitals in urban Kano such as Aminu Kano teaching hospital, Murtala Mohd specialist hospital, Sir Sanusi general hospital and National Orthorpedic hospital Dala among others could all undergo Plasma treatment if adequate arrangement and provision of this type of technology is provided. Investigation revealed that approximately, about $70 \%$ of these hospital wastes are hazardous. Although, a tendency of increase in hazardous hospital wastes is apparent due to continue increase in the number of hospitals from time to time.

This is in line with observation of Abdel- salem (2009) where he noted that in various nations medical and hazardous waste are poorly handle and this has been due largely to the fact that waste directly from house hold and medical waste are jointly disposed, hence generating a severe health hazard to the community, surrounding and metropolitan employees. However, the wastes generated from hospital is currently identified as one of the major problem with negative consequences on the population and the environment in particular all the way through direct or indirect contact.

\section{Plasma Gasification}

Zhao et al. (2010) reported that Plasma technology is capable of treating each and every category of waste or blend municipal solid waste, industrial solid or waste water, medical waste, sewage sludge etc. A talented technique but can obliterate waste at a high temperature is what is known as plasma gasification which utilized electricity to change wastes in to diverse shape. Gay (2014) observed that plasma technology enhance environmental performance and significantly lessen emission and minimized the quantity of waste, the vitrified slag which could be either landfill or serve as filler material for example, in road construction. Although, the machinery involved considerable electrical effort to generate or recover from the (MSW).

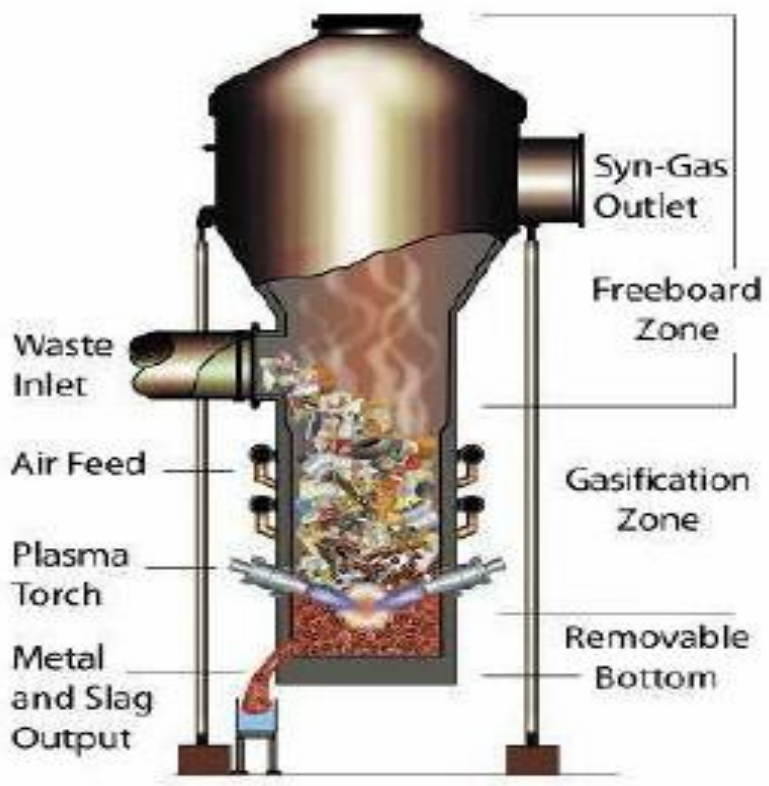

Figure 1: A Plasma Gasifier

Source: Araya et al. (2006)
Araya et al. (2006) observed that subsequent heating of the gasifier through the action of the plasma torch system very close to the base of the reactor vessel take place. Inside the gasifier, the organic feed such as MSW, biomass, coal, remnants and auto shredder is charge in the vertical reactor vessel at atmospheric pressure. In addition air and /or steam can play a significant role and made available to aid with pyrolysis and gasification. Similarly, the syngas leaving the apex of the gasifier maintained a maximum temperature of above $100^{\circ} \mathrm{C}$. Gasification usually occur when the temperature is very high generated by the plasma torch system, at the base of the gasifier vessel $2-5 \%$ of the energy in to the gasification system is been used by the plasma torch and at least $80 \%$ of the overall energy provided for can develop the syngas.

Zhao et al. (2010) stressed that plasma has an advantages over incinerators in that the main source of energy in plasma reactors is electricity, rather than energy released by combustion and independent of waste being destroyed. The greater concentration of energy coupled with high temperature are possible in plasma system and therefore, enhance chemical reactions.

\section{Conclusion}

The invention of Plasma technology and the role play in wastes treatment is still not in familiar terms in Kano state regardless of it importance in waste management. The study has shown that some environmental restrictions ranging from unreliable electricity supply and cost have to a great degree hampered the utilization and efficient performance of this type of technology. The study found that waste generation and disposal practice is always increasing but unfortunately, designated disposal site could not alone contain the volume of waste thus, the need for plasma technology is very important. In addition, it is hope that this study would generate further discussion on waste management and related issues in planning a sound and sustainable waste management solution.

\section{References}

[1] Anyaegbunam, F, N, C. (2013) Sustainable power generation by Plasma physics : American Journal of Engineering Research 2(8),65-75.

[2] Anyaegbunam, F,N, C. (2014) Hazardous waste vitrification by Plasma Gasification process. Journal of Environmental Science and Toxicology and Food Technology 8(3), 15-19.

[3] Anyaegbunam, F, N, C. (2013) Environmentally Friendly and Sustainable Municipal solid waste management in Abuja. International Journal of Engineering Science Invention 2(7), 42-50.

[4] Araya, M. Yuji, T. Watanabe, T. Kashihara, J. Sumida,Y. (2006) Application to cleaning of waste plastics surface using atmospheric thermal plasma jet. Journal of Thin solid film 515(9),4301-4307.

[5] Abdel -Salem, M,M. (2009) Hospital waste management in El-Beheira Governorate, Egypt. Journal of Environmental Management 91(2010), 618-629.

[6] Byun, Y. Cho, M. Chun, J. Namkung, W. Donlee, H. Jang, S. Sukkim, Y. Lee, J. Lee, C. \& Huang, S. (2011)

\section{Volume 4 Issue 11, November 2015}


Hydrogen recovery from the thermal plasma gasification of solid waste. Journal of Hydrogen Materials 190(1-3),317-323.

[7] Consonni, S. Giugliano, M. Mussarutto, A. \& Saccani, M, C. (2011) Material and energy recovery in integrated waste management systems: Project overview and main results. Journal of Waste Management 31(9-10),205765

[8] Danthurebandara, M. Vanderreydt, I. \& Van acker, K. (2014) The environmental performance of plasma gasification within the frame work of enhance Landfill Mining: A Life Cycle Assessment study. A Conference paper.

[9] Gomez, E. Rani, D. A. Cheeseman, C, R. Deegan, D. Wise, M. and Boccaccini, A, R. (2008) Thermal plasma technology for the treatment of wastes: A critical review. Journal of Hazardous Materials 161 (2-3),.614626.

[10] Galeno, G. Minutillo, M. \& Perna, A. (2011) From waste to electricity through integrated plasma gasification/ fuel cell (IPGFC) system. International Journal of Hydrogen Energy 36(2),1692-1701

[11] Gandhul, H. (2015) Plasma gasification: From a dirty city to a Heavenly place and from waste solids to a clean fuel. International Journal of Innovative Research in Science Technology 1(11), 2349-6010

[12] Gray, L. (2014) Plasma Gasification as a viable wasteto- energy treatment of municipal solid waste. MANE6960- Solid and Hazardous waste prevention and control Engineering, Renselaer Hartford. USA.

[13] Jannelli, E. Minutillo, M. \& Perma, A. (2014) Hydrogen from intermittent renewable energy sources as plasma gas in integrated plasma gasification system for waste treatment and electric energy production. Proceedings of SEEP Conference 23-25 Dubai, (UAE).

[14].Moustakas, K. Sixydis, G. Haralambous, K, J. and Loizidou, M. (2007) Analysis of results from the operation of a pilot plasma gasification / Vitrification unit for optimizing its performance. Journal of Hazardous material 151 ( 2-3),473-80.

[15] Mountouris, A. Voutsas, E. Tassios, D. (2005) Solid waste plasma gasification:Equilibrium model development and energy analysis. Journal of Energy, Conservation and Management 47 (2006),1723-1737.

[16] Shekdar, A, U. (2008) Sustainable solid waste management: An integrated approach for Asian countries. Journal of Waste Management. 29 (4),14381448.

[17]Zhao, P. Ni, G. Jiang, Y. Chen, L. Chen, M. \& Meng, Y. (2010) Destruction of inorganic municipal solid waste incinerator fly ash in a DC arc plasma furnace. Journal of Hazardous Materials. 181 (1-3),580-585.

[18]Zhang, Q. Dor, L. Fenigshtein, D. Yang, W. \& Blasiak, W. (2012) Gasification of municipal solid waste in the plasma Gasification Melting process. Journal of Applied Energy 90(1),106-112. 